\title{
Penggunaan Kalium Permanganat sebagai Oksidan Etilen untuk Memperpanjang Daya Simpan Pisang Raja Bulu
}

\section{Using of Permanganate Potassium as Ethylene Oxidant for Extending Storability of Raja Bulu Banana}

\author{
Mei Lianti Arista, Winarso Drajad Widodo*, dan Ketty Suketi
}

\author{
Departemen Agronomi dan Hortikultura, Fakultas Pertanian, Institut Pertanian Bogor \\ (Bogor Agricultural University), Jl. Meranti, Kampus IPB Darmaga, Bogor 16680, Indonesia \\ Telp.\&Faks.62-251-8629353 e-mail agronipb@indo.net.id \\ *Penulis untuk korespondensi: wd_widodo@yahoo.com
}

Disetujui 6 November 2017/Published online 14 November 2017

\begin{abstract}
Banana is a climacteric fruit which has an advance rate of respiration. The increasing of respiration rate in the ripening process is triggered by emission of ethylene in autocatalytic. The respiration rate of the banana can be inhibited by deactivated the ethylene using chemical treatments, such as $\mathrm{KMnO}_{4}$. The aim of this study are to study the inhibition of Raja Bulu banana respiration rate during storage using $\mathrm{KMnO}_{4}$ and have $\mathrm{KMnO}_{4}$ concentration to extend the shelf-life of Raja Bulu banana. This study was conducted during a month since from February until March 2013 at Postharvest Laboratory, Department of Agronomy and Horticulture, Faculty of Agriculture, Bogor Agricultural University. The experimental design was arranged in a randomized complete block design with 4 treatments and 5 replications, which were $\mathrm{KMnO}_{4} 7.5 \%, 15 \%$, $22.5 \%$, and control (without $\mathrm{KMnO}_{4}$ ). Collected data was analyzed using F test method and if the treatments result showed a significantly affect was analyzed by Duncan Multiple Range Test (DMRT) test method. Parameters measured was the respiration rate, peel color index, shelf-life, weight reduction, edible part, rind firmness, total soluble solids, total titratable acids, and vitamin $C$. The results showed that the use $\mathrm{KMnO}_{4}$ of $7.5 \%, 15 \%$, and $22.5 \%$ can inhibited the respiration rate of banana during storage so that suspend the peak of the climacteric Raja Bulu banana 1-2 days compared to control. The use $\mathrm{KMnO}_{4}$ of 7.5\%, 15\%, and $22.5 \%$ was not affect the quality of the physical and chemical of Raja Bulu banana.
\end{abstract}

Keywords: climacteric, postharvest, respiration rate, ripening

\begin{abstract}
ABSTRAK
Pisang merupakan buah klimakterik dengan laju respirasi yangmeningkat. Peningkatan laju respirasi selama proses pematangan dipicu oleh emisi etilen secara autokatalitik. Laju respirasi pisang dapat dihambat dengan menonaktifkan etilen dengan menggunakan perlakuan kimiawi, salah satunya dengan penggunaan $\mathrm{KMnO}_{4}$. Tujuan penelitian ini adalah mempelajari penghambatan laju respirasi pisang Raja Bulu selama penyimpanan menggunakan $\mathrm{KMnO}_{4}$ dan memperoleh konsentrasi $\mathrm{KMnO}_{4}$ untuk memperpanjang daya simpan pisang Raja Bulu. Penelitian ini dilakukan selama 1 bulan mulai dari Februari sampai Maret 2013 di Laboratorium Pascapanen, Departemen Agronomi dan Hortikultura, Fakultas Pertanian, Institut Pertanian Bogor. Rancangan percobaan yang digunakan adalah Rancangan Kelompok Lengkap Teracak dengan 4 perlakuan dan 5 ulangan, yaitu $\mathrm{KMnO}_{4} 7.5 \%, 15 \%$, 22.5\%, dan kontrol (tanpa $\mathrm{KMnO}_{4}$ ). Data yang diperoleh dianalisis dengan uji $\mathrm{F}$ dan perlakuan yang mempengaruhi dianalisis dengan uji Duncan Multiple Range Test (DMRT). Parameter yang diukur adalah laju respirasi, indeks skala warna kulit buah, umur simpan, susut bobot, edible part, kekerasan kulit buah, padatan terlarut total, asam tertitrasi total, dan kandungan vitamin C. Hasil percobaan menunjukkan bahwa penggunaan $\mathrm{KMnO}_{4} 7.5 \%$, 15\%, dan 22.5\% dapat menghambat laju respirasi pisang selama penyimpanan sehingga menunda puncak klimakterik pisang Raja Bulu 1-2 hari dibandingkan kontrol. Penggunaan $\mathrm{KMnO}_{4}$ 7.5\%, 15\%, dan 22.5\% tidak mempengaruhi kualitas fisik dan kimia pisang Raja Bulu.
\end{abstract}

Kata kunci: klimakterik, laju respirasi, pascapanen, pematangan 


\section{PENDAHULUAN}

Pisang merupakan salah satu komoditas buah-buahan yang memiliki produksi terbesar di Indonesia. Produksi pisang Indonesia pada tahun 2010 mencapai 5755073 ton dan tahun 2011 meningkat menjadi 6132695 ton (BPS 2012). Potensi produksi pisang yang besar tersebut belum dikembangkan sebagai keunggulan yang memiliki daya saing kuat sehingga pemanfaatan pisang kurang terealisasikan dengan baik.

Pisang termasuk produk hortikultura yang tidak tahan lama, mudah rusak, dan meruah. Hal ini disebabkan oleh tingginya tingkat respirasi buah dan produksi etilen endogen selama proses pematangan setelah dipanen. Menurut Sutowijoyo (2013) semakin tua umur panen pisang maka pencapaian kematangan semakin cepat. Pisang Raja Bulu yang berumur 100 hari setelah antesis (HSA) mencapai kematangan pada hari ke-12. Menurut Santoso dan Purwoko (1995) selama proses pematangan pascapanen terjadi berbagai perubahan fisik dan kimia pada buah. Perubahan secara fisik yang menyebabkan turunnya mutu buah antara lain: perubahan tekstur, susut bobot, layu, dan keriput. Perubahan kimia yang terjadi yaitu perubahan komposisi karbohidrat, asam organik, dan aroma. Menurut Satuhu dan Supriyadi (1999) salah satu cara yang dapat dilakukan untuk memperlambat penurunan mutu buah pascapanen adalah dengan penggunaan kalium permanganat $\left(\mathrm{KMnO}_{4}\right)$.

Perlakuan $\mathrm{KMnO}_{4}$ bertujuan untuk mengoksidasi etilen yang diproduksi oleh pisang sehingga proses pematangan buah dapat dihambat. Dengan perlakuan ini pisang dapat dipertahankan kesegarannya hingga 3 minggu dengan disimpan pada suhu ruang (Cahyono 2009). Penggunaan $\mathrm{KMnO}_{4}$ secara langsung tidak dianjurkan karena bentuknya yang cair akan menurunkan penampilan fisik buah, sehingga diperlukan suatu bahan pembawa. Beberapa bahan pembawa $\mathrm{KMnO}_{4}$ yang telah diteliti antara lain: arang tempurung kelapa yang dibuat menjadi pellet (Sholihati 2004), zeolit (Jannah 2008), dan tanah liat (Kholidi 2009; Mulyana 2011; Sabrina 2012; Sugistiawati 2013).

$$
\text { Hasil penelitian Mulyana }
$$

menunjukkan bahwa daya simpan pisang terlama (14 hari penyimpanan) dan masih layak dikonsumsi diperoleh pada penggunaan $30 \mathrm{~g}$ bahan oksidan etilen (campuran $27.75 \mathrm{~g}$ tanah liat dan $2.25 \mathrm{~g} \mathrm{KMnO}_{4}$ ) dalam bungkus serat nilon. Selain itu setelah 12 hari penyimpanan, penggunaan $30 \mathrm{~g}$ bahan oksidan etilen dalam serat nilon juga menunjukkan susut bobot terkecil. Penggunaan bahan pembungkus serat nilon dengan $30 \mathrm{~g}$ bahan oksidan etilen dapat direkomendasikan untuk digunakan dalam penyimpanan pisang Raja Bulu. Penelitian lain juga telah dilakukan oleh Sugistiawati (2013) menunjukkan bahwa penggunaan 1 kemasan (30 g) bahan oksidan etilen dalam serat nilon menghasilkan waktu simpan terpanjang yaitu 15 hari, sedangkan penggunaan 3 kemasan (3 x 10 g) bahan oksidan etilen menghasilkan waktu simpan terpendek yaitu 12 hari.

Pada penelitian sebelumnya penentuan waktu simpan belum dikaitkan dengan pengukuran laju respirasi. Pengukuran laju respirasi perlu dilakukan dalam penyimpanan pascapanen pisang untuk mengetahui efektivitas oksidan etilen. Menurut Phan et al. (1986) laju respirasi merupakan petunjuk yang baik bagi daya simpan buah setelah panen karena intensitas respirasi dianggap sebagai ukuran laju jalannya metabolisme dan sering dianggap sebagai petunjuk potensi daya simpan buah.

\section{BAHAN DAN METODE}

Penelitian ini dilaksanakan dalam percobaan laboratorium yang dilakukan pada bulan Februari sampai Maret 2013 di Laboratorium Pascapanen, Departemen Agronomi dan Hortikultura, Fakultas Pertanian, Institut Pertanian Bogor.

Bahan utama yang digunakan dalam penelitian ini adalah pisang Raja Bulu (Musa sp. $\mathrm{AAB}$ Group) dengan umur panen \pm 100 hari setelah pembungaan yang diperoleh dari petani di Darmaga, Bogor. Bahan yang digunakan untuk perlakuan terdiri atas: kalium permanganat $\left(\mathrm{KMnO}_{4}\right)$ sebagai oksidan etilen, tanah liat, kertas serat nilon, kotak kardus, stoples plastik, kertas koran, selang, silica gel, larutan Natrium Hipoklorit, larutan phenoftalein, tepung kanji, akuades, iodine $0.01 \mathrm{~N}$, dan $\mathrm{NaOH} 0.1 \mathrm{~N}$. Alatalat yang digunakan terdiri atas: oven, loyang, timbangan analitik, kosmotektor, penetrometer, refraktometer, alat-alat titrasi, pisau, dan mortar.

Percobaan dilakukan dengan menggunakan Rancangan Kelompok Lengkap Teracak (RKLT). Rancangan ini terdiri atas 4 taraf perlakuan, yaitu perlakuan menggunakan bahan oksidan etilen 30 g dengan konsentrasi; $\mathrm{KMnO}_{4} 7.5 \%$ (P1) ; $\mathrm{KMnO}_{4}$ $15 \%$ (P2) ; $\mathrm{KMnO}_{4} 22.5 \%$ (P3). Sebagai pembanding dari ketiga perlakuan tersebut, digunakan perlakuan tanpa bahan oksidan etilen sebagai kontrol (P4). Setiap perlakuan diulang sebanyak 5 kali, sehingga terdapat 20 satuan percobaan. Data yang diperoleh dianalisis dengan uji F dan perlakuan yang mempengaruhi dianalisis 
dengan uji Duncan Multiple Range Test (DMRT) pada taraf $5 \%$.

Pelaksanaan kegiatan meliputi pembuatan pasta tanah liat, persiapan bahan oksidan etilen, persiapan buah, pengemasan dan penyimpanan buah serta pengamatan. Pembuatan pasta tanah liat dilakukan 3 hari sebelum perlakuan. Tanah liat diperoleh dari Kebun Percobaan Cikabayan, Darmaga, Bogor. Tanah liat yang telah diperoleh dihancurkan terlebih dahulu hingga halus kemudian dikeringkan dengan oven selama \pm 24 jam. Tanah liat dibagi sesuai perlakuan bahan oksidan etilen, yaitu: 250 g, 790 g, dan 925 g. Selanjutnya persiapan bahan oksidan etilen dilakukan 2 hari sebelum perlakuan. Tanah liat dicampurkan dengan $\mathrm{KMnO}_{4}$ sesuai perlakuan yaitu $\mathrm{KMnO}_{4} 7.5 \%$ (campuran $925 \mathrm{~g}$ tanah liat dan 75 g KMnO$_{4}$ ), $\mathrm{KMnO}_{4} 15 \%$ (campuran $250 \mathrm{~g}$ tanah liat dan $500 \mathrm{~g}$ oksidan etilen P3), dan $\mathrm{KMnO}_{4} 22.5 \%$ (campuran $790 \mathrm{~g}$ tanah liat dan $230 \mathrm{~g} \mathrm{KMnO}_{4}$ ). Campuran tanah liat dan $\mathrm{KMnO}_{4}$ diencerkan dengan akuades dan diaduk hingga rata berbentuk pasta. Hasil campuran dikeringkan dengan oven selama \pm 48 jam dengan suhu $80^{\circ} \mathrm{C}$. Setelah kering, bahan tersebut dihancurkan hingga berbentuk serbuk, kemudian dikeringkan lagi dengan oven selama \pm 24 jam. Bahan oksidan etilen yang telah kering dikemas dalam kertas serat nilon (kertas pembungkus teh celup) sesuai dengan perlakuan. Perlakuan di dalam kardus untuk percobaan penyimpanan buah dikemas dengan bobot $30 \mathrm{~g}$ dan perlakuan di dalam stoples plastik untuk pengukuran laju respirasi buah dikemas dengan bobot $3.75 \mathrm{~g}$.

Pisang yang digunakan pada penelitian ini adalah Pisang Raja Bulu yang berumur \pm 100 hari setelah pembungaan yang diperoleh dari petani di Darmaga, Bogor. Pisang disortasi untuk menentukan kelayakan buah yang digunakan dalam percobaan. Setelah itu pisang dibersihkan menggunakan desinfektan larutan Natrium Hipoklorit 10\%, lalu dikeringanginkan dan dikemas. Kemasan yang digunakan adalah kotak kardus berukuran 30 × 21 x $13 \mathrm{~cm}$. Setiap kotak kardus diisi 1 sisir pisang yang terbagi dua beserta oksidan etilen sesuai perlakuan dan silica gel sebanyak 5 g. Selanjutnya kotak kardus ditutup dan diberi lakban. Pada penggunaan kemasan stoples plastik, pisang yang dimasukkan dalam stoples plastik hanya 2 buah beserta oksidan etilen sesuai perlakuan dan silica gel sebanyak 5 g. Stoples plastik ditutup dan diberi selang. Penyimpanan dilakukan di Laboratorium Pascapanen Departemen Agronomi dan Hortikultura IPB, Darmaga, Bogor dengan suhu ruang.
Peubah yang diamati meliputi: laju respirasi, karakter fisik, dan karakter kimia. Karakter fisik yaitu indeks skala warna kulit buah, umur simpan, susut bobot buah, bagian buah yang dapat dimakan (edible part), dan kekerasan kulit buah. Karakter kimia yaitu padatan terlarut total, asam tertitrasi total, dan vitamin C. Pengukuran laju respirasi dilakukan setiap hari dari awal perlakuan hingga pisang telah membusuk. Pengukuran laju respirasi dilakukan setelah pengukuran volume udara bebas dalam stoples, bobot pisang, dan penginkubasian selama 3.5 jam. Indeks skala warna kulit buah juga diamati setiap hari untuk melihat perubahan warna kulit buah setiap harinya yang digunakan sebagai parameter umur simpan. Susut bobot, bagian buah yang dapat dimakan (edible part), kekerasan kulit buah, padatan terlarut total (PTT), asam tertitrasi total (ATT), dan vitamin C diamati ketika buah telah mencapai indeks skala 100\% kuning.

\section{HASIL DAN PEMBAHASAN}

\section{Laju Respirasi Buah}

Laju respirasi pisang berpola klimakterik. Pola klimakterik terjadi karena kenaikan jumlah $\mathrm{CO}_{2}$ yang kemudian menurun sampai mendekati proses kelayuan (Gambar 1). Pisang tanpa penggunaan $\mathrm{KMnO}_{4}$ (P4) mengalami laju respirasi tercepat (puncak klimakterik) pada 8 hari setelah perlakuan (HSP). Hal tersebut ditunjukkan pisang tanpa penggunaan $\mathrm{KMnO}_{4}$ memiliki laju respirasi rata-rata tertinggi yaitu $367.32 \mathrm{mg}$ $\mathrm{CO}_{2} / \mathrm{kg}$.jam dibandingkan ketiga perlakuan lainnya dengan penggunaan $\mathrm{KMnO}_{4}$ (Tabel 1). Hal ini diduga pisang tidak mengalami penghambatan pematangan sehingga laju respirasi berjalan lebih cepat. Menurut Tranggono dan Sutardi (1990) umur simpan buah akan lebih bertahan lama jika laju respirasi rendah, sedangkan umur simpan yang pendek ditandai dengan laju respirasi yang tinggi.

Puncak klimakterik pisang ditandai oleh adanya kematangan secara fisiologis dan morfologis. Puncak klimakterik pisang dengan perlakuan $\mathrm{KMnO}_{4} \quad 7.5 \% \quad(\mathrm{P} 1), \quad \mathrm{KMnO}_{4} \quad 15 \%$ (P2), dan $\mathrm{KMnO}_{4} 22.5 \%$ (P3) berturut-turut terjadi pada 10 HSP, 10 HSP, dan 9 HSP (Gambar 1). Ketiga perlakuan tersebut memiliki laju respirasi rata-rata yang tidak berbeda nyata (Tabel 1). Hal ini menunjukkan bahwa penggunaan $\mathrm{KMnO}_{4}$ pada ketiga perlakuan memiliki pengaruh yang sama dalam menghambat pematangan pisang. Pematangan pisang dihambat dengan menekan 
laju respirasi pisang selama penyimpanan sehingga menunda puncak klimakterik pisang Raja Bulu 1-2 hari dibandingkan kontrol dan daya simpan pisang dapat diperpanjang. Sama halnya dengan penelitian Sugistiawati (2013) yang menyatakan bahwa penggunaan $\mathrm{KMnO}_{4}$ dapat memperpanjang daya simpan pisang Raja Bulu 24 hari dibandingkan kontrol.

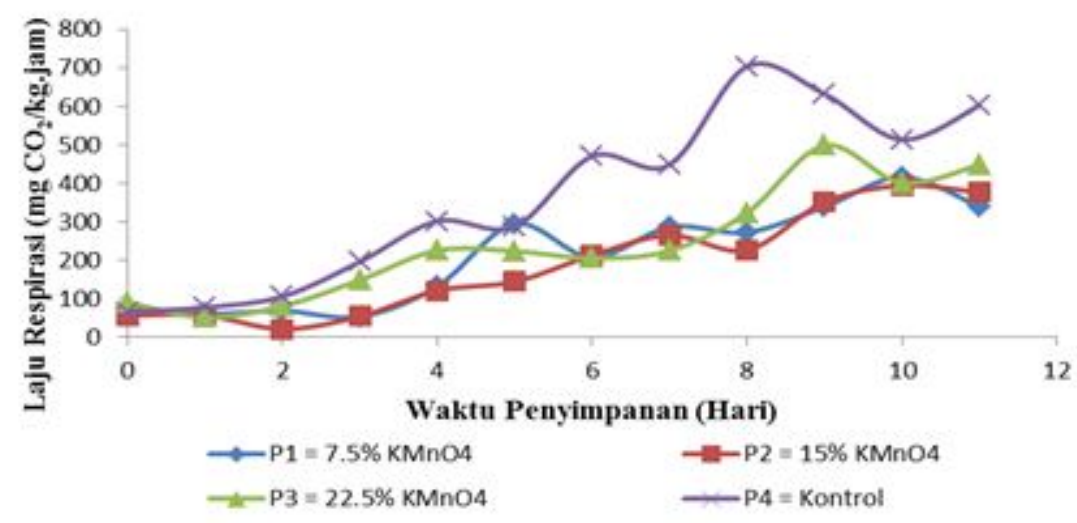

Gambar 1. Pola klimakterik respirasi dalam pematangan pisang raja bulu

Hasil tersebut didukung oleh kondisi yang terjaga dari pengaruh etilen bahan penelitian lain. Pengemasan buah menggunakan stoples plastik tertutup diduga memperkecil masuknya pengaruh etilen yang menguap dalam ruang penyimpanan ke dalam kemasan sehingga $\mathrm{KMnO}_{4}$ yang digunakan menjadi efektif menghambat laju respirasi buah selama pematangan.

Tabel 1 Rata-rata laju respirasi pisang Raja Bulu

\begin{tabular}{lc}
\hline Perlakuan & Laju respirasi (mg/kg.jam) ${ }^{\mathrm{a}}$ \\
\hline $\mathrm{P} 1: \mathrm{KMnO}_{4} 7.5 \%$ & $208.37 \mathrm{~b}$ \\
$\mathrm{P} 2: \mathrm{KMnO}_{4} 15 \%$ & $193.39 \mathrm{~b}$ \\
$\mathrm{P} 3: \mathrm{KMnO}_{4} 22.5 \%$ & $227.75 \mathrm{~b}$ \\
$\mathrm{P} 4:$ Kontrol & $367.32 \mathrm{a}$
\end{tabular}

Keterangan: ${ }^{a}$ Angka-angka pada kolom yang sama yang diikuti huruf yang sama menunjukkan hasil yang tidak berbeda nyata pada uji DMRT taraf $5 \%$.

Timbulnya cendawan pada pisang selama penyimpanan diduga dapat mendukung laju produksi $\mathrm{CO}_{2}$ yang dihasilkan menjadi meningkat. Keadaan tersebut sama halnya dengan penelitian Sholihati (2004) yang menyatakan bahwa peningkatan produksi $\mathrm{CO}_{2}$ terjadi kembali diduga akibat pertumbuhan kapang dan laju respirasi yang terukur pada pisang Raja Bulu. Menurut Trinurasih (2012) peningkatan laju produksi $\mathrm{CO}_{2}$ belimbing pada hari ke-16 disebabkan oleh munculnya bintik-bintik hitam yang merupakan indikator pertumbuhan cendawan. Menurut Hayati (2013) salak di dalam stoples yang terserang cendawan menghasilkan perubahan nilai $\mathrm{CO}_{2}$ menjadi lebih tinggi.

\section{Kualitas Fisik Buah}

Pengamatan kualitas fisik buah terdiri atas: perubahan warna, susut bobot, kekerasan kulit buah, dan bagian buah yang dapat dimakan. Perubahan warna diamati menggunakan derajat kekuningan kulit buah yang dinilai dengan skala hijau sampai $100 \%$ kuning yang mengacu pada hasil penelitian Sugistiawati (2013). Hasil percobaan menunjukkan bahwa pisang mengalami perubahan warna secara bertahap mulai dari skala hijau, 10-15\% kuning, 75\% kuning, 90\% kuning, dan 100\% kuning. Beberapa pisang mengalami perubahan warna langsung dari skala hijau ke $75 \%$ kuning.

Serangan penyakit crown end root dan antraknosa diduga menjadi penyebab perubahan indeks skala warna kulit pisang yang cepat selama penyimpanan. Selain itu produksi etilen yang tinggi dalam pisang mempengaruhi pematangan buah secara cepat yang ditandai dengan hilangnya warna hijau pada kulit buah sehingga penggunaan $\mathrm{KMnO}_{4}$ menjadi kurang efektif dalam menghambat pematangan. Buah yang semakin matang ditandai dengan perubahan warna kulit buah dari hijau menjadi kuning. Perubahan warna kulit buah yang umumnya terjadi selama pematangan akibat degradasi klorofil. Menurut Robinson (1999) perubahan warna kulit pisang dari hijau gelap menjadi kuning karena selama pematangan terjadi degradasi klorofil secara bertahap yang tidak tertutupi oleh pigmen karotenoid.

Indeks skala warna kulit buah digunakan sebagai parameter dalam mengukur umur simpan pisang dengan mengamati pisang secara visual. 
Pisang yang telah mencapai indeks skala warna 5 ditentukan umur simpannya yang dihitung sejak awal mulai perlakuan. Hasil pengukuran umur simpan buah hingga mencapai skala warna 5 disajikan pada Tabel 2.

Tabel 2 Kualitas fisik pisang Raja Bulu

\begin{tabular}{lcccc}
\hline Perlakuan & $\begin{array}{c}\text { Umur simpan } \\
(\mathrm{HSP})^{\mathrm{a}}\end{array}$ & $\begin{array}{c}\text { Susut bobot } \\
(\%)\end{array}$ & $\begin{array}{c}\text { Kekerasan } \\
\text { kulit buah } \\
(\mathrm{mm} / 50 \mathrm{~g} / 5 \text { detik) }\end{array}$ & Edible part (\%) \\
\hline $\mathrm{P} 1: \mathrm{KMnO}_{4} 7.5 \%$ & 12.394 & 21.836 & 63.163 & 54.741 \\
$\mathrm{P}^{\mathrm{K}} \mathrm{KMnO}_{4} 15 \%$ & 12.458 & 20.285 & 43.514 & 57.318 \\
$\mathrm{P} 3 \mathrm{KMnO}_{4} 22.5 \%$ & 12.500 & 21.539 & 54.615 & 55.979 \\
$\mathrm{P} 4: \mathrm{Kontrol}^{\mathrm{a}}$ & 12.140 & 21.657 & 55.881 & 55.155 \\
\hline
\end{tabular}

Keterangan: ${ }^{\mathrm{a} H S P}$ : hari setelah perlakuan.

Penggunaan $\mathrm{KMnO}_{4}$ dengan beberapa konsentrasi yang berbeda tidak mempengaruhi umur simpan buah selama 12 hari penyimpanan (Tabel 2). Hal ini karena beberapa pisang banyak yang terserang penyakit, antara lain crown end root dan antraknosa. Gejala penyakit crown end root dan antraknosa ditimbulkan pada saat penyimpanan.

Gejala penyakit crown end root mulai muncul pada hari ke-7 penyimpanan yang ditandai dengan munculnya pembusukan yang terjadi pada pangkal sisir pisang (Gambar 2). Menurut Satuhu dan Supriyadi (1999) pembusukan pada pangkal sisir pisang merupakan gejala crown end root yang disebabkan oleh infeksi jasad renik Colletotrichum musae. Menurut Lassois (2010) crown end root atau busuk mahkota disebabkan oleh jamur miselium seperti Colleotrichum musae yang dapat mempengaruhi kualitas buah karena perkembangan nekrosis pada buah dan dapat memicu pematangan awal pisang selama pengiriman.

Pada hari ke-9 penyimpanan gejala yang muncul berupa terdapatnya perubahan warna pada bagian-bagian tertentu dari hijau menjadi kuning, kemudian menjadi cokelat tua atau hitam yang disebut penyakit antraknosa (Gambar 2). Menurut Cahyono (2009) penyakit antraknosa disebabkan oleh cendawan Colletotrichum musae. Infeksi cendawan tersebut akan mempercepat kerusakan buah ketika sudah matang dalam penyimpanan sehingga buah menjadi cepat membusuk.
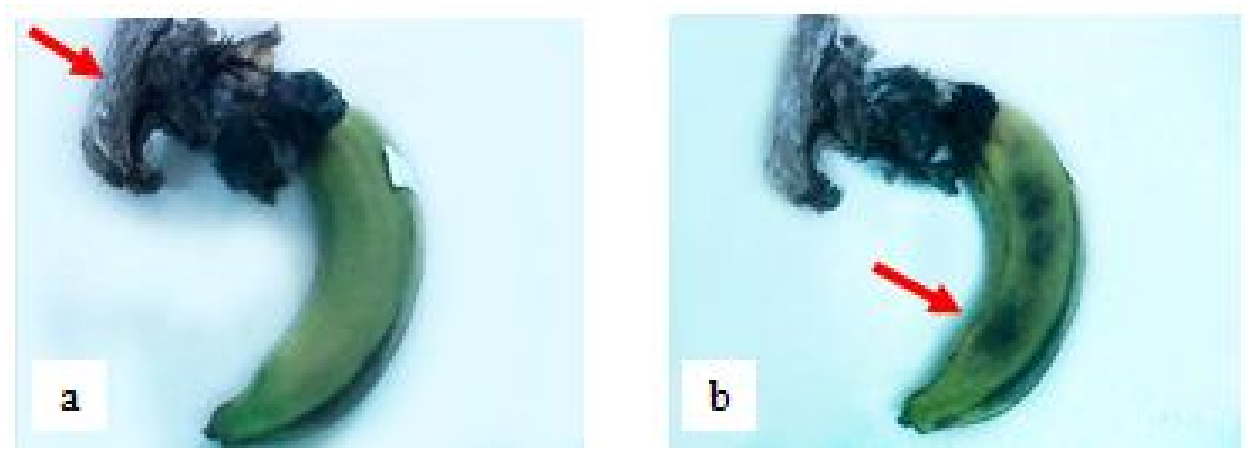

Gambar 2. Gejala serangan penyakit a) crown end root, b) antraknosa

Faktor lain yang mempengaruhi pematangan pisang secara cepat adalah kondisi tempat penyimpanan. Tempat penyimpanan yang digunakan dalam penelitian ini bersamaan dengan penelitian lain. Bahan penelitian yang digunakan sama-sama memproduksi etilen yang tinggi sehingga etilen dapat menguap dan menyebar ke seluruh penyimpanan. Hal ini mengakibatkan produksi etilen dalam pisang menjadi semakin banyak dan $\mathrm{KMnO}_{4}$ yang digunakan sebagai perlakuan dalam penelitian ini kurang efektif dalam menghambat pematangan pisang. Menurut Soesanto (2006) etilen dapat mengganggu penyimpanan buah yang disimpan dalam ruang simpan yang sama karena pengaruhnya pada buah lain di sekitarnya sehingga akan mempercepat pematangannya.

Penggunaan $\mathrm{KMnO}_{4}$ tidak mempengaruhi susut bobot pisang selama penyimpanan (Tabel 2). Susut bobot pisang tidak dapat dipertahankan tetap rendah selama penyimpanan. Hal ini diduga pisang tidak mengalami penghambatan pematangan selama penyimpanan sehingga kehilangan bobot akibat proses transpirasi dan respirasi yang terjadi di dalam pisang relatif sama pada semua perlakuan. Menurut penelitian 
Sugistiawati (2013) bobot pisang menyusut seiring dengan lamanya penyimpanan. Menurut Lodh et al. (1971) setelah 2 sampai 4 hari bobot pisang Dwarf Cavendish mulai berkurang bersamaan dengan perubahan-perubahan pada proses pematangan. Purwoko dan Juniarti (1998) mengemukakan bahwa persentase susut bobot pisang Cavendish mengalami peningkatan selama pematangan. Pisang mengalami kehilangan air karena aktivitas respirasi dan transpirasi. Kehilangan bobot pisang akibat transpirasi dapat menyebabkan pengeriputan yang mengurangi nilai keragaan pisang. Menurut Sabrina (2012) susut bobot pisang yang meningkat menunjukkan bahwa pisang menggunakan cadangan makanannya untuk proses metabolisme.

Penggunaan $\mathrm{KMnO}_{4}$ tidak mempengaruhi kekerasan kulit pisang selama penyimpanan (Tabel 2). Kekerasan kulit pisang memiliki hubungan dengan susut bobot. Semakin rendah susut bobot maka semakin lunak kulit pisang. Menurut Sugistiawati (2013) semakin lama penyimpanan maka semakin lunak kulit pisang. Menurut penelitian Adeyemi dan Oladiji (2009) terjadi peningkatan kadar air dan perubahan komposisi mineral selama pematangan. Hal ini menjelaskan tekstur pelunakan pisang menjadi parameter dari hasil pematangan. Menurut Matto et al. (1986) menjadi lunaknya buah disebabkan oleh perombakan protopektin yang tidak larut menjadi pektin yang larut atau hidrolisis zat pati atau lemak. Menurut Ali dan Goukh (2005) selama pematangan tomat, pektin yang larut meningkat sedangkan jumlah pektin yang tidak larut semakin menurun.

Penggunaan $\mathrm{KMnO}_{4}$ tidak mempengaruhi edible part (Tabel 2). Edible part berkaitan dengan kandungan air dalam daging dan kulit pisang. Menurut Simmonds (1966) persentase bobot daging pisang pada awal perkembangan buah sangat rendah, sedangkan persentase bobot kulit sangat tinggi. Semakin matangnya pisang maka bobot daging pisang bertambah disertai sedikit demi sedikit pengurangan bobot kulitnya.
Pengurangan ini disebabkan perubahan selulosa dan hemiselulosa dalam kulit menjadi zat pati selama proses pematangan. Menurut Diennazola (2008) uji korelasi yang dilakukan antara edible part dengan rasio daging pisang dan kulit pisang memiliki korelasi yang positif. Hal ini diduga adanya pengaruh kandungan air daging pisang yang semakin meningkat selama penyimpanan karena terjadinya perpindahan air dari kulit pisang ke daging pisang. Perpindahan air tersebut menyebabkan bobot kulit pisang semakin berkurang dan bobot daging pisang semakin bertambah.

\section{Kualitas Kimia Buah}

Pengamatan kualitas kimia buah terdiri atas: PTT, ATT, dan kandungan vitamin C. Penggunaan $\mathrm{KMnO}_{4}$ tidak mempengaruhi PTT pisang selama penyimpanan. Pisang pada semua perlakuan menunjukkan nilai yang sama dalam mempertahankan PTT pisang (Tabel 3). Hal ini diduga pisang tidak mengalami penghambatan pematangan selama penyimpanan sehingga perombakan pati menjadi gula relatif sama. Menurut Sarode dan Tayade (2009) PTT pisang meningkat dengan meningkatnya lama penyimpanan. Menurut Soltani et al. (2010) PTT pisang meningkat selama pematangan dari 7.8\% Brix pada tahap hijau menjadi $18.6 \%$ Brix pada tahap kematang penuh (kuning).

Penggunaan $\mathrm{KMnO}_{4}$ tidak mempengaruhi ATT pisang selama penyimpanan. Pisang pada penggunaan $\mathrm{KMnO}_{4}$ tidak menunjukkan adanya perbedaan dalam mempertahankan ATT dibandingkan pisang tanpa penggunaan $\mathrm{KMnO}_{4}$ (Tabel 3). Penggunaan $\mathrm{KMnO}_{4}$ tidak dapat mempertahankan kandungan asam pisang tetap rendah selama penyimpanan. Menurut Tapre dan Jain (2012) nilai keasaman pisang meningkat secara bertahap sampai mencapai kematangan penuh. Menurut Santoso dan Purwoko (1995) kandungan asam organik pisang tinggi pada kematangan penuh dan setelah itu akan menurun.

Tabel 3 Kualitas kimia pisang Raja Bulu

\begin{tabular}{|c|c|c|c|c|}
\hline Perlakuan & $\begin{array}{c}\text { PTT } \\
\left({ }^{\circ} \text { Brix }\right)\end{array}$ & $\begin{array}{c}\text { ATT } \\
\text { (mg/100 g bahan) }\end{array}$ & Rasio PTT/ATT & $\begin{array}{c}\text { Vitamin C } \\
\text { (mg/100 g bahan) }\end{array}$ \\
\hline $\mathrm{P} 1: \mathrm{KMnO}_{4} \quad 7.5 \%$ & 25.859 & 54.230 & 0.494 & 45.575 \\
\hline P2: $\mathrm{KMnO}_{4} 15 \%$ & 28.863 & 55.147 & 0.544 & 44.347 \\
\hline P3: $\mathrm{KMnO}_{4} 22.5 \%$ & 25.703 & 52.300 & 0.504 & 38.060 \\
\hline P4: Kontrol & 27.108 & 59.050 & 0.493 & 44.795 \\
\hline
\end{tabular}

Keterangan : PTT $=$ Padatan terlarut total; ATT $=$ Asam tertitrasi total

Penggunaan $\mathrm{KMnO}_{4}$ tidak mempengaruhi rasio PTT/ATT pisang selama penyimpanan (Tabel 3). Hal tersebut berkaitan dengan nilai PTT dan ATT pisang pada semua perlakuan menunjukkan nilai yang sama sehingga rasio dari keduanya atau rasio PTT/ATT juga menunjukkan tidak adanya perbedaan. Rasio PTT/ATT memiliki keterkaitan hubungan dalam penentuan 
rasa yang terkandung dalam pisang. Menurut Sugiarto et al. (1991) yang paling penting dalam menentukan selera konsumen pada jeruk manis adalah rasio gula/asam atau keseimbangan antara rasa manis dan asam.

Penggunaan $\mathrm{KMnO}_{4}$ tidak mempengaruhi kandungan vitamin $\mathrm{C}$ pisang selama penyimpanan (Tabel 3). Hal ini diduga pergerakan pola peningkatan kandungan vitamin $\mathrm{C}$ dalam pisang berbeda-beda selama pematangan namun tidak menunjukkan adanya penghambatan pematangan pisang. Menurut Miller dan Bazore (1945) dalam Pantastico (1986) kandungan vitamin C mengikuti pola yang tidak teratur selama pertumbuhan dan perkembangan buah. Menurut Purwoko dan Juniarti (1998) kandungan vitamin C berfluktuasi pada buah yang mengalami perlakuan pascapanen. Menurut Pujimulyani (2009) vitamin $\mathrm{C}$ yang ada di dalam daging buah mudah mengalami kerusakan akibat $\mathrm{O}_{2}$ karena teroksidasi.

\section{KESIMPULAN}

Penggunaan $\mathrm{KMnO}_{4} 7.5 \%$, 15\%, dan 22.5\% dapat menghambat laju respirasi pisang selama penyimpanan sehingga menunda puncak klimakterik pisang Raja Bulu 1-2 hari dibandingkan kontrol. Penggunaan $\mathrm{KMnO}_{4} 7.5 \%$, $15 \%$, dan $22.5 \%$ tidak mempengaruhi kualitas fisik dan kimia pisang Raja Bulu.

\section{DAFTAR PUSTAKA}

Adeyemi OS, Oladiji AT. 2009. Compositional changes in banana (Musa ssp.) fruits during ripening. J Biotech. 8(5):858-859.

Ali MB, Goukh ABAA. 2005. Changes in pectic substances and cell wall degrading enzymes during tomato fruit ripening. UKJ Agric Sci. 13(2):202-222.

[BPS] Badan Pusat Statistik. 2012. Produksi buah-buahan di Indonesia. [Internet]. [diunduh 2013 Maret 10]. Tersedia pada: http://www.bps.go.id.

Cahyono B. 2009. Pisang Usaha Tani dan Penanganan Pascapanen. Yogyakarta (ID): Kanisius.

Diennazola R. 2008. Pengaruh sekat dalam kemasan terhadap umur simpan dan mutu buah pisang Raja Bulu [skripsi]. Bogor (ID): Institut Pertanian Bogor.
Hayati N. 2013. Pengaruh pelilinan pada ujung buah salak pondoh pascapanen dengan suhu yang berbeda terhadap investasi penyakit [skripsi]. Bogor (ID): Institut Pertanian Bogor.

Jannah UF. 2008. Pengaruh bahan penyerap larutan kalium permanganat terhadap umur simpan pisang Raja Bulu [skripsi]. Bogor (ID): Institut Pertanian Bogor.

Kholidi. 2009. Studi tanah liat sebagai pembawa kalium permanganat pada penyimpanan buah pisang Raja Bulu [skripsi]. Bogor (ID): Institut Pertanian Bogor.

Lassois L, Jijakli MH, Chillet M, Bellaire LL. 2010. Preharvest factors involved in postharvest disease development and integrated control methods. Plant Disease. 94(6):648-658.

Lodh SB, Ravel P, Selvaraj Y, Kohli RR. 1971. Biochemical changes associated with growth and development of 'Dwarf Cavendish’ banana. Ind J Hort. 28(1):3845.

Matto AK, Murata T, Pantastico EB, Chachin K, Phan CT. 1986. Perubahan-perubahan Kimiawi selama Pematangan dan Penuaan. Di dalam: Pantastico EB, editor. Fisiologi Pascapanen, Penanganan, dan Pemanfaatan Buah-buahan dan Sayursayuran Tropika dan Sub Tropika. Kamariyani, penerjemah. Yogyakarta (ID): Gajah Mada University Pr. Terjemahan dari: Postharvest Physiology, Handling, and Utilization of Tropical and Sub Tropical Fruits and Vegetables.

Mulyana E. 2011. Studi pembungkus bahan oksidator etilen dalam penyimpanan pascapanen pisang Raja Bulu (Musa sp. AAB GROUP) [skripsi]. Bogor (ID): Institut Pertanian Bogor.

Pantastico EB. 1986. Fisiologi Pascapanen, Penanganan, dan Pemanfaatan Buahbuahan dan Sayur-sayuran Tropika dan Sub Tropika. Kamariyani, penerjemah. Yogyakarta (ID): Gajah Mada University Pr. Terjemahan dari: Postharvest Physiology, Handling, and Utilization of Tropical and Sub Tropical Fruits and Vegetables. 
Phan CT, Pantastico EB, Ogata K, Chachin K. 1986.Respirasi dan Puncak Respirasi. Di dalam: Pantastico EB, editor. Fisiologi Pascapanen, Penanganan, dan Pemanfaatan Buah-buahan dan Sayursayuran Tropika dan Sub Tropika. Kamariyani, penerjemah. Yogyakarta (ID): Gajah Mada University Pr. Terjemahan dari: Postharvest Physiology, Handling, and Utilization of Tropical and Sub Tropical Fruits and Vegetables.

Pujimulyani D. 2009. Teknologi Pengolahan Sayur-sayuran dan Buah-buahan. Yogyakarta (ID): Graha Ilmu.

Purwoko BS, Juniarti D. 1998. Pengaruh beberapa perlakuan pascapanen dan suhu penyimpanan terhadap kualitas dan daya simpan buah pisang Cavendish. Bul Agron. 26(2):19-28.

Robinson JC. 1999. Bananas and Plantains. New York (US): CABI.

Sabrina B. 2012. Efektivitas bahan pembungkus oksidator etilen untuk memperpanjang masa simpan buah pisang Raja Bulu [skripsi]. Bogor (ID): Institut Pertanian Bogor.

Santoso B, Purwoko BS. 1995. Fisiologi dan Teknologi Pascapanen Tanaman Hortikultura Indonesia. Indonesia Australia Eastern Universities Project.

Sarode SC, Tayade NH. 2009. Physiochemical changes during ripening in 'Williams, Zeling, and Grand Nain' banana. J Dairying Foods \& Home Sci. 28(3-4):220224.

Satuhu S, Supriyadi A. 1999. Pisang Budidaya, Pengolahan dan Prospek Pasar. Jakarta (ID): Penebar Swadaya.

Sholihati. 2004. Kajian penggunaan bahan penyerap etilen kalium permanganat untuk memperpanjang umur simpan pisang Raja (Musa paradisiaca var. Sapientum L.) [tesis]. Bogor (ID): Institut Pertanian Bogor.

Simmonds NW. 1966. Edisi ke-2. Bananas. London (UK): Longman.

Soesanto L. 2006. Penyakit Pascapanen. Yogyakarta (ID): Kanisius.

Soltani M, Alimardani R, Omid M. 2010. Prediction of banana quality during ripening stage using capacitance sensing system. Aust J Crop Sci. 4(6):443-447.

Sugiarto M, Hardianto, Suhardi. 1991. Sifat fisik dan kimiawi beberapa varietas jeruk manis (Citrus senensis L. Osbeck). J Hort. 1(3):39-43.

Sugistiawati. 2013. Studi penggunaan oksidator etilen dalam penyimpanan pascapanen pisang Raja Bulu (Musa sp. AAB Group) [skripsi]. Bogor (ID): Institut Pertanian Bogor.

Sutowijoyo D. 2013. Kriteria kematangan pascapanen pisang Raja Bulu dan pisang Kepok [skripsi]. Bogor (ID): Institut Pertanian Bogor.

Tapre AR, Jain RK. 2012. Study of advanced maturity stages of banana. International Journal of Advanced Engineering Research and Studies. 1(3):272-274.

Tranggono, Sutardi. 1990. Biokimia dan Teknologi Pascapanen. Yogyakarta (ID): Pusat Antar Universitas, Gadjah Mada University.

Trinurasih S. 2012. Kombinasi perlakuan hot water treatment dan $\mathrm{CaCl}_{2}$ untuk mencegah kerusakan fisiologi buah belimbing (Averrhoa carambola L.) [skripsi]. Bogor (ID): Institut Pertanian Bogor. 